\title{
Społeczne i prawne normy dotyczące obcych i przybyszów w Biblii Hebrajskiej
}

Social and Legal Norms Concerning Strangers and Newcomers in the Hebrew Bible

\author{
PIOTR BRIKS \\ Uniwersytet Szczeciński - Instytut Historyczny \\ e-mail: piotr.briks@usz.edu.pl \\ ORCID: 0000-0001-7929-2840
}

\begin{abstract}
Fragments of the Bible have recently became an important argument in the discussion about the attitude that should be adopted by Europeans referring to their JudeoChristian roots with reference to refugees/immigrants from Africa and the Middle East. Considering that the quoted texts are mainly from the Old Testament, it is worth looking more closely at what the Hebrew Bible actually says about the postulated attitude of the Israelites to the strangers and newcomers. The author presents fragments directly related to the problem of receiving or not accepting refugees and examples of hospitality towards strangers. These texts come from different periods in the history of Israel and from different theological traditions, so they could be treated as representative of the teaching of the Hebrew Bible in this topic. However, this is not a complete picture, but only orders and norms referring to the alien determined by the term and consistently translated by the "stranger", very often in the plural. An analysis of the meaning of this concept in Hebrew language and culture, the legitimacy of using plural translations (when in the original is single) and supplementing the above statement with other terms used in the Hebrew Bible to describe strangers or newcomers (such as derivatives from the root נכר or leads to surprising conclusions.
\end{abstract}

KEYWORDs: newcomer, stranger, guest, refugees, ger.

SŁowa KLUCze: przybysz, obcy, gość, uchodźcy, ger.

$\mathrm{M}$ igracje stanowią nieodłączny element historii człowieka. Były one wynikiem nieszczęść, poszukiwania lepszych warunków rozwoju albo po prostu przyjętego sposobu życia. Nic więc dziwnego, że temat ten pojawia się też wielokrotnie na kartach Biblii. Wędrowali sami Izraelici i nierzadko spotykali się z wędrowcami, obcymi czy migrującymi ludami. Tradycja biblijna zawiera wiele obrazów, historii, nakazów oraz pouczeń dotyczących tej problematyki. Odnośne fragmenty z Biblii stały się w ostatnim czasie ważkim argumentem w dyskusji dotyczącej postawy, jaką powinni przyjąć Europejczycy odwołujący się do korzeni judeochrześcijańskich wobec przybyszów z Afryki i Bliskiego Wschodu. Wiele z przytaczanych tekstów pochodzi ze Starego Testamentu, warto więc zweryfikować, co faktycznie mówi Biblia Hebrajska na temat postulowanej postawy wobec przybyszów oraz przyjrzeć się normom, jakie obowią- 
zywały obcych starających się o schronienie w Izraelu lub po prostu szukających pomocy $^{1}$. Nie jest to wbrew pozorom zadanie proste. Przede wszystkim z powodu złożoności terminologicznych. W biblijnym języku hebrajskim istnieje kilka terminów określających obcych czy przybyszów. Określane przy ich pomocy osoby różniły się statusem społecznym, stopniem integracji, kontekstem, w jakim się pojawiały itp. ${ }^{2}$ Różnice te jednak bardzo często zacierają się nie tylko w tłumaczeniach (także w przekładach Biblii na język polski), ale i w słownikach tematycznych. Dopiero zestawienie odmiennych rodzajów przybyszów/ obcych, stosowanych wobec nich norm i postaw, oraz uwzględnienie wymagań prawa gościnności ${ }^{3}$, pozwala dostrzec wzorce zachowań promowanych w Biblii Hebrajskiej. W zgiełku dyskusji politycznych nietrudno o nadinterpretacje i uproszczenia. Tym bardziej warto pokusić się o próbę systematycznej i krytycznej analizy poszczególnych tekstów normatywnych w Biblii Hebrajskiej odnoszących się do tego problemu.

\section{Biblijny imperatyw gościnności wobec obcych}

Najczęściej cytowane teksty biblijne odnoszące się do cudzoziemców i sposobu ich traktowania wydają się zaskakująco zbieżne w swojej wymowie. Przekazują podobny wzorzec postępowania bez znaczenia, z jakiej tradycji czy nurtu teologicznego pochodzą i w jakim czasie powstawały ${ }^{4}$. Ze względów formalnych można podzielić je na dwie grupy. Pierwsza z nich to bezpośrednie nakazy/ wskazówki co do postępowania wobec obcego czy przybysza. Wyliczyć tu należy przede wszystkim następujące fragmenty: Wj 22,20; 23,9.12; Kpł 19,33-34; Pwt 24,14; Za 7,10; Jr 7,6-7. Grupa druga to teksty promujące określone wzorce zachowań: M1 3,5; Iz 14,1; Ps 146,9, a w pewnym sensie także Hi 31,32, czyli fragment obrończej mowy Hioba, w której wskazuje na swoje starania, aby nie

1 Na temat (ograniczonych) możliwości bezpośredniego stosowania norm i zwyczajów dotyczących gościnności z okresu starotestamentowego w odniesieniu do problemów współczesności patrz: L.R. Martin, „Old Testament Foundations for Christian Hospitality”, VE 35 (2014) 1-9.

2 Terminologię biblijną (oraz grecką) dotyczącą gościnności oraz samo zagadnienie gościnności w całości Biblii i antycznych tekstach greckich omawia J. Pytel sumarycznie w: „Pojęcie gościnności w literaturze biblijnej i greckiej”, RBL 30 (1977) 172-182, a bardziej szczegółowo w: Gościnność w Biblii. Studium źródłowo-porównawcze (Poznań: Księgarnia Świętego Wojciecha 1990).

3 W Biblii Hebrajskiej nie ma słowa określającego gościnność, są jedynie teksty ją opisujące lub normujące (por. T.R. Hobbs, „Hospitality in the First Testament and the Teleological Fallacy”, JSOT $26(2001) 4$.

4 Ze względu na ilość i jednoznaczność napomnień i nakazów dotyczących gościnności, możemy przyjąć, że wynikały one ze starszej niż ich zapis tradycji i stanowiły immanentny element kultury Izraela. 
popełnić grzechu. Twierdzi m.in., że „obcy (רֵֵ) nigdy nie sypiał na dworze, podróżnym (ארֵ $\left.\boldsymbol{\kappa}^{5}\right)$ otwierałem podwoje"6.

Oczywiście obie grupy tekstów są od siebie zależne i wzajemnie się uzupełniają. Przykładem ich syntezy może być fragment Pwt 10,18-19, który za wzór postępowania stawia samego Boga: „On wymierza sprawiedliwość sierotom i wdowom, miłuje cudzoziemca (격), udzielając mu chleba i odzienia. Wy także miłujcie

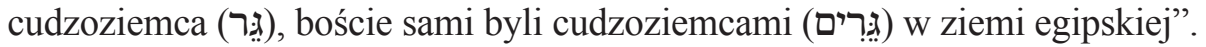

Całemu powyższemu wyliczeniu (teksty prezentujące pozytywny stosunek wobec cudzoziemca przebywającego w Izraelu) przeciwstawia się tylko jedną przestrogę przed „obcym”, znajdującą się w deuterokanonicznej Księdze Syracha $(11,29.34 ; 12,1)$ : „Nie wprowadzaj do swego domu każdego człowieka,

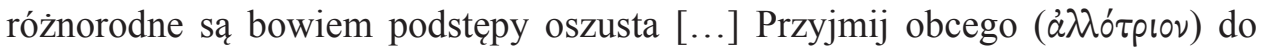
domu, a wtrąci cię w zamieszanie i oddali cię od twoich najbliższych [...]. Jeśli chcesz dobrze czynić, zważ, komu masz czynić, a będą ci wdzięczni za twe dobrodziejstwa".

Do powyższego katalogu należałoby dołączyć także przykłady (niekiedy wręcz heroicznej) gościnności wobec obcych. Pierwszym z nich jest historia wizyty wędrowców ${ }^{7}$ u Abrahama $(\operatorname{Rdz} 18,1-33)^{8}$. Patriarcha, goszcząc przybyszów, spotkał w nich samego Boga i w rezultacie otrzymał zapowiedź narodzin protoplasty ludu Izraela9. Tradycja żydowska, a za nią chrześcijańska, wskazują nawet miejsce tego spotkania, które z czasem stało się sanktuarium $i$ bardzo popularnym miejscem pielgrzymowania wiernych ${ }^{10}$. Po wizycie u Abrahama dwóch spośród jego gości udaje się do jego bratanka Lota, przebywające-

5 אָרֵח najczęściej oznacza „drogę, ścieżkę" (także w znaczeniu przenośnym). Tutaj paralelizm każe thumaczyć to słowo jako „podróżny”, „wędrowiec” lub wokalizować jako imiesłów od ארֵחח).

6 Jeśli nie zaznaczono inaczej, polskie thumaczenia tekstów biblijnych przytoczono za: Biblia Tysiąclecia (wyd. 5 [Poznań: Pallottinum 2017]).

7 Tożsamość gości Abrahama jest nieznana i w tradycjach bywa różnie interpretowana.

8 Na temat różnych aspektów gościnności na przykładzie Abrahama zob.: J.M. Cohen, „Abraham’s Hospitality”, JBQ34/3 (2006) 168-172; Z. Pawłowski, „O Panie, nie omijaj twego stugi. Gościnność Abrahama w horyzoncie tego, co niemożliwe (Rdz 18,1-15)", BPTh 9/2 (2016) 55-69.

9 Odniesienia do gościnności Abrahama w tradycji izraelskiej i wczesnochrześcijańskiej zob.: A.E. Arterbury, ,Abraham's Hospitality among Jewish and Early Christian Writers: A Tradition History of Gen 18: 1-16 and Its Relevance for the Study of the New Testament", PRSt 30 (2003) 359-376. Podobne przykłady nagrodzenia gościnności to wdowa z Sarepty (1 Krl 17,16) czy Szunamitka (2 Krl 4,18-37).

10 Fakt, że w okolicach Hebronu zachowały się ślady po izraelskich, pogańskich i chrześcijańskich sanktuariach upamiętniających wizytę wędrowców u Abrahama, świadczy o nadzwyczajnej wadze, jaką przywiązywano do tego wydarzenia. Obecnie jako Mamre najczęściej wskazywane jest Khirbet es-Sibte (rzadziej Ain Sebta opodal Ramat al-Chalil). Więcej na temat tradycji i lokalizacji związanych z Mamre zob.: W. Zwickel, „Das Heiligtum von Mamre”, BN 101 (2000) 27-28; D. Jericke, „Hebron”, Das wissenschaftliche Bibellexikon im Internet (Hrsg. M. Bauks, K. Koenen, S. Alkier) (Stuttgart 2006-2016) https://www.bibelwissenschaft.de/de/stichwort/20809/ [dostęp: 9.07.2019]. Kolejnym dowodem na kulturotwórcze oddziaływanie tego wydarzenia biblijnego jest jedna z najsłynniejszych scen ikonograficznych - uwieczniona m.in. w arcydziele A. Rublowa Trójca Święta (szerzej na temat kulturowego kontekstu tego przedstawienia zob.: G. Bunge, The 
go w Sodomie. Kiedy mieszkańcy Sodomy dowiedzieli się o przebywających u Lota przybyszach, zbiegli się, żeby dokonać na nich gwałtu. Lot, chcąc ochronić gości za wszelką cenę, był nawet gotów wydać na pastwę tłumu własne córki (Rdz 19,8). Podobny przekaz znajdujemy w historii efraimskiego lewity, który znalazł gościnę u pewnego starca w mieście Gibea. Także w tym przypadku mieszkańcy miasta zbiegli się, by dopuścić się gwałtu na przybyszu i podobnie jak Lot, gospodarz wolał wydać swoją córkę niż gościa ( $\left.\mathrm{Sdz} 19,16-24^{11}\right)$. Abstrahując od historyczności tych przekazów, chodzi w nich o imperatyw gościnności, czyli sam pomysł takiego rozwiązania problemu agresywnego zachowania wobec gościa, który prawdopodobnie żadnemu współczesnemu Europejczykowi nie przyszedłby do głowy ${ }^{12}$.

Tego typu obrazy, podobnie jak przytoczone teksty, stanowią element przekazu biblijnego dotyczącego stosunku Izraelitów do obcych i przybyszów. Historie przodków i wynikające z nich wzorce postępowania odgrywały w procesie kształtowania się postaw ludzi Wschodu rolę nie mniej ważną niż bezpośrednie nakazy.

Powyższe teksty i liczne przykłady traktowania obcych, opisane na kartach Biblii, nie pozostawiają wątpliwości. Jednym z obowiązków Izraelity, którego przodkowie doświadczali niegdyś niedoli pobytu na obczyźnie (najczęściej przywoływany jest Egipt ${ }^{13}$ ) i tułaczki, jest pomoc, albo przynajmniej życzliwy stosunek do obcokrajowca, wędrowca i przybysza. Sądząc po ilości tych napomnień, można nawet przypuszczać, że jest to jeden z podstawowych obowiązków Izraelity. Na marginesie warto jednak zauważyć, że we wszystkich tekstach dotyczących gościnności brak jest bezpośrednich nakazów ugoszczenia brata, krewnego, przyjaciela czy nawet pobratymca, a przecież prawo gościnności musiało obowiązywać także (a nawet przede wszystkim) w ich przypadku ${ }^{14}$. Wymienienie explicite obcych, obok pozostających na marginesie życia społecznego sierot i wdów, świadczy dobitnie, że gościnność czy zwykła pomoc szwankowała właśnie w stosunku do tych grup społecznych ${ }^{15}$. I nic w tym dziwnego, gdyż Izraelici należeli do kręgu kultur, w których świat dzielono na swoich i obcych ${ }^{16}$.

Rublev Trinity: The Icon of the Trinity by the Monk-painter Andrei Rublev (Crestwood, NY - New York: St. Vladimir's Seminary Press 2007).

11 Ostatecznie zgwałcona została żona przybysza, w wyniku czego zmarła. Karą była wyprawa wszystkich pokoleń Izraela przeciwko Beniaminitom i niemal całkowite wyniszczenie pokolenia Beniamina.

12 Zob. także gościnność wdowy z Sarepty (1 Krl 17,10-24) oraz kobiety z Szunemu wobec Elizeusza (2 Krl 4,8-37).

$13 \quad$ Np. Wj 22,20; 23,9; Kpł 19,34; Pwt 10,19; 16,12; 24,18.

14 Tak Rdz 29,13; Kpł 19,33-34; 24,22; pośrednio ugoszczenie braci przez Józefa w Egipcie (Rdz 43,31-34); Iz 58,7 itp.

$15 \quad$ Np. Sdz 19,12.15.20.

16 Jeden $\mathrm{z}$ wielu przykładów to prawo nakazujące inaczej traktować niewolnika pobratymca, a inaczej obcego: Kpł 25,39-50. 
Tylko ci pierwsi cieszyli się pełnią godności i praw. Stan ten korygować mogły jedynie surowe napomnienia. Czy były one jednak bezwarunkowe? Do kogo były skierowane i do kogo naprawdę się odnosiły? Czy wymienione powyżej teksty (pojawiające się $\mathrm{w}$ argumentacji za przyjmowaniem migrantów), to wszystkie wskazania, którymi mógł lub powinien kierować się Izraelita? I wreszcie, co w dyskusji nad ewentualną aplikacją nakazów biblijnych do obecnej sytuacji jest jeszcze bardziej istotne, jaka polityka państwa wobec obcych i migrantów była postulowana w Biblii Hebrajskiej?

\section{Określenia i rodzaje „obcych” w Biblii Hebrajskiej}

Należy odnotować, że we wszystkich przywołanych do tej pory fragmentach biblijnych na określenie obcego stosuje się termin 쪼 (z wyjątkiem Hi 31,32b, gdzie pojawia się ארֵ i oczywiście Syr 11,34) oraz że termin ten w przytoczonych tekstach, w odniesieniu do obcych używany jest w liczbie pojedynczej (z wyjątkiem

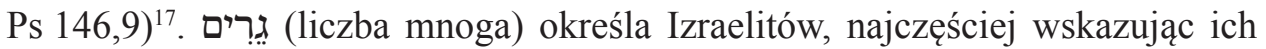
pobyt w Egipcie lub podkreślając przemijalność wszystkiego, co posiadają (bo są tylko „przechodniami” na ziemi) ${ }^{18}$. W liczbie pojedynczej termin 초 stosowany jest w hebrajskim biblijnym w odniesieniu do osób ,nie swoich" ${ }^{19}$, takich jak przybysz, wędrowiec, tułacz, ktoś obcego pochodzenia (choć niekoniecznie

17 Termin ten jest tylko jednym z możliwych na określenie kogoś obcego, przybysza, wędrowca. Analizę aż ośmiu tego typu określeń zob.: R. Achenbach, ,gêr - nåkhrî - tôshav - zâr. Legal and Sacral Distinctions regarding Foreigners in the Pentateuch", The Foreigner and the Law: Perspectives from the Hebrew Bible and the Ancient Near East (red. R. Achenbach - R. Albertz - J. Wöhrle) (BZABR 16; Wiesbaden: Harrassowitz 2011) 29-52. Zob. także: R. Ebach, Das Fremde und das Eigene: Die Fremdendarstellungen des Deuteronomiums im Kontext israelitischer Identitätskonstruktionen (BZAW 471, Berlin - Boston, MA: De Gruyter 2014).

18 Wj 22,20; 23,9; Kpł 19,34; 25,23; Pwt 10,19; 16,12; 24,18; 1 Krn 29,15; Jr 35,7.

19 Bardzo obszerne opracowanie teologicznego i socjologicznego rozumienia terminu Powtórzonego Prawa, ale także w jej bliskowschodnim kontekście, przedstawia M.A. Awabdy (Immigrants and Innovative Law: Deuteronomy's Theological and Social Vision for the גFAT 2/67; Tübingen: Mohr Siebeck 2014]). Zob. także: C. Bultmann, Der Fremde im antiken Juda. Eine Untersuchung zum sozialen Typenbegriff "ger" und seinem Bedeutungswandel in der alttestamentlichen Gesetzgebung (FRLANT 153; Göttingen: Vandenhoeck \& Ruprecht 1992); B. Lang, „Die Fremden in der Sicht des Alten Testaments", Wahrnehmung des Fremden. Christentum und andere Religionen (red. R. Kampling - B. Schlegelberger) (SchrDB 12; Berlin 1996) 11-13; J.E. Ramírez Kidd, Alterity and Identity in Israel. The $7 x$ in the Old Testament (BZAW 283; Berlin - New York: de Gruyter 1999); M. Zehnder, Umgang mit Fremden in Israel und Assyrien. Ein Beitrag zur Anthropologie des "Fremden" im Licht antiker Quellen (BWANT 168; Stuttgart: W. Kohlhammer 2005); V. Haarmann, JHWH-Verehrer der Völker. Die Hinwendung von Nichtisraeliten zum Gott Israels in alttestamentlichen Überlieferungen (AThANT 91; Zürich: Theologischer Verlag Zürich 2008); G. Baumann et al. (wyd.), Zugänge zum Fremden. Methodisch hermeneutische Perspektiven zu einem biblischen Thema (LPhThB 25; Frankfurt am Main: Peter Lang 2012). 
cudzoziemiec $)^{20}$. Nie musiał to być jednak ktoś zupełnie obcy, właśnie co przybyły $^{21}$. Nazwanie kogoś 저 sugeruje nawet, że został on już w pewien sposób przyjęty, zaakceptowany, zyskał status gościa, a przynajmniej o tego typu status się ubiegał (por. Rdz 21,23). Nie stawał się on przez to samo oczywiście „swój”, ale nie był też całkowicie „obcy”22. Najczęściej, choć nie zawsze, רגֵ oznaczało kogoś biednego i potrzebującego pomocy (patrz Kpł 25,35) 23 בגֵ zdany był na łaskę i opiekę swojego patrona, który stosował do niego prawa gościa, on w zamian musiał zaś podporządkować się prawom gospodarza i być wobec niego lojalny $^{24}$. W Rdz 21,23 znajdujemy nakaz uroczystego (na Boga) zobowiązania się przybysza do lojalności, działania na rzecz gospodarza i jego ojczyzny (,tej

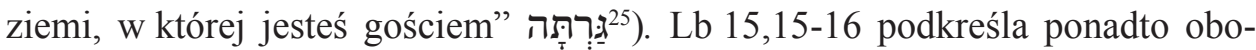
wiązek podporządkowania się prawu, które w takim samym stopniu obowiązuje

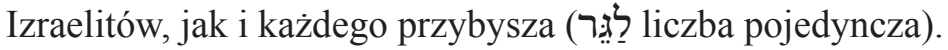

„Obcy” o statusie må mógł w pewnym zakresie włączyć się w życie religijne (a nawet kult), m.in. rytuał oczyszczenia (Lb 19,2-10), obchodzenie szabatu (Wj 20,10; Pwt 5,14), uczestnictwo w świętach (Pwt 16,11.14), post w Jom Kippur (Kpł 16,29), składanie ofiar (Kpł 17,8; 22,18; Lb 15,14nn), obrzezanie i uczestnictwo w Passze (Wj 12,48-49; Lb 9,14) ${ }^{26}$. Obowiązywały go także przynajmniej niektóre z obowiązujących w Izraelu zakazów, np. kazirodztwa (Kpł 18,26), przepisy odnoszące się do czystości pokarmów (Kpł 17,10-16, zob. jednak Pwt 14,21) oraz posłuszeństwo wobec samego JHWH (Kpł 20,2; por. Ez 14,5-8) 27 .

J. Schreiner - R. Kampling, Bliźni, obcy, nieprzyjaciel z perspektywy Starego i Nowego Testamentu (Kraków: WAM 2001) 32.

21 Rozróżnienia pomiędzy różnego rodzaju „obcymi” w Biblii Hebrajskiej zob.: Achenbach - Albertz -Wöhrle (red.), The Foreigner and the Law.

22 Aramejski rzeczownik גיור oznacza wręcz prozelitę; podobne znaczenie przybrało hebrajskie słowo גר w okresie rzymskim. Na temat nabycia statusu zob.: Rdz 47,3-6 (rodzina Józefa w Egipcie); Wj 2,18-22 (Mojżesz u Madianitów). Podobną pozycję społeczną określa pokrewny termin arabski jār (por. Iz 14,1).

23 Zdarzały się jednak także wyjątki. Obcy mógł posiadać majątek, gospodarstwo domowe (Wj 12,48n), a nawet izraelskich niewolników (Kpł 25,47-54). Zob.: B. Wells, „The Quasi-Alien in Leviticus 25”, The Foreigner and the Law: Perspectives from the Hebrew Bible and the Ancient Near East (red. R. Achenbach - R. Albertz - J. Wöhrle) (BZABR 16; Wiesbaden: Harrassowitz 2011) 135-156.

W.R. Smith, Lectures on the Religion of the Semites (New York: D. Appleton 1889) 75-79; S.M. Olyan, Rites and Rank: Hierarchy in Biblical Representations of Cult (Princeton: Princeton University Press 2000) 74-81.

25 Forma czasownikowa qal perfectum 2 os. r.m 1.poj. od rdzenia גור

26 Obszerne studium na temat dopuszczania lub niedopuszczania obcych do rytuałów i obrzędów w Biblii Hebrajskiej zob.: S. Olyan, Rites and Rank, rozdz. 3 (wadą tego opracowania jest brak rozróżnienia pomiędzy poszczególnymi, pojedynczymi obcymi, a obcymi jako kolektywem).

27 R. Albertz (,From Aliens to Proselytes. Non-Priestly and Priestly Legislation Concerning Strangers", The Foreigner and the Law: Perspectives from the Hebrew Bible and the Ancient Near East [red. R. Achenbach - R. Albertz - J. Wöhrle] [BZABR 16; Wiesbaden: Harrassowitz 2011] 53-70) zwraca uwagę na zmianę podejścia do obcych w zależności od okresu, w którym powstawały konkretne teksty (okoliczności). W niniejszym rozważaniu tego typu zmiany są sygnalizowane, ale nie 
W Biblii Hebrajskiej spotykamy jednak także inne terminy na określenie obcych czy przybyszów ${ }^{28}$. Dla niniejszego opracowania najważniejszym z nich jest: נכר bardzo często kojarzone są w Biblii Hebrajskiej z obcymi bogami, z którymi Izraelici nie powinni mieć styczności (Rdz 35,2.4, Pwt 31,16; 32,12, Joz 24,23; Sdz 10,16; $1 \mathrm{Sm} 7,3 ; 2$ Krn 14,2; 33,15; Ps 81,10; Dn 11,39; Ml 2,11). Podobnie jak od obcych bogów, także od samych obcych Izraelici powinni trzymać się z dala (Ne 9,2; 13,30; Ps 144,7.11; Ez 44,7-9). Według Jewish Virtual Library określeni w ten sposób obcy „,zachowują więzy ze społecznością swojego pochodzenia i starają się utrzymać swój dotychczasowy status polityczny lub społeczny" ${ }^{\prime 30}$. Konotacja tych terminów jest przeważnie negatywna ${ }^{31}$. Określani są nimi nie tylko nielojalni czy wrogo nastawieni przybysze, ale także po prostu obcy (etnicznie, kulturowo, religijnie), którzy samą swoją obecnością lub przywiązaniem do własnych praw i tradycji mogą spowodować pęknięcia w monolicie Izraela. Tak jest w Ez 44,6-7, gdzie w wizji proroka Ezechiela dotyczącej świątyni JHWH sam fakt wpuszczenia

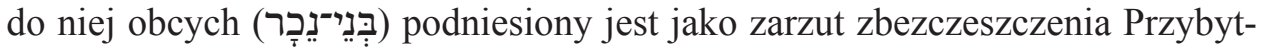
ku i złamania warunków Przymierza ${ }^{32}$. Podobną wymowę mają także Lb 1,51; Ps 54,5; Iz 1,7; Jr 2,25 czy Kpł 22,253. Teksty te wskazują na obcych (najczęściej w liczbie mnogiej) jako źródło zagrożenia dla Izraela lub jego prawowierności, czasami nawet bez podawania przyczyn lub rodzaju takiego zagrożenia.

wpływają na ostateczną wymowę tekstów biblijnych, z wyjątkiem uwagi, że stosunek do obcych zawsze był wypadkową wielu funkcji i nie był uwarunkowany dogmatycznie.

Zob.: Y. Hoffman, „The Conception of 'Other Gods' in Deuteronomistic Literature”, Concepts of the Other in Near Eastern Religions (red. I. Alon - I. Gruenwald - I. Singer) (IOS 14; Leiden - New York - Köln: Brill 1994) 103-118.

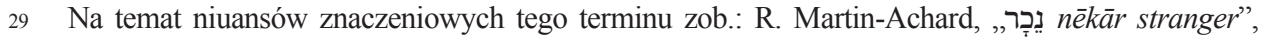

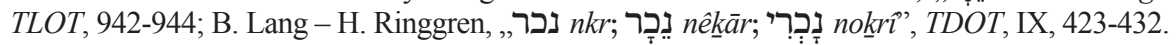

30 „Strangers and Gentiles”, www.jewishvirtuallibrary.org/strangers-and-gentiles [dostęp: 23.03.2019].

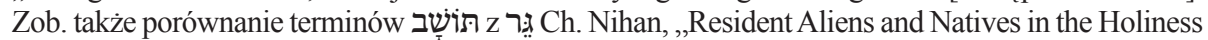
Legislation”, The Foreigner and the Law: Perspectives from the Hebrew Bible and the Ancient Near East (red. R. Achenbach - R. Albertz - J. Wöhrle) (BZABR 16; Wiesbaden: Harrassowitz 2011) 118. Na specyficzne znaczenie terminu נָכְְר wskazują A.Ophir i I. Rosen-Zvi (Goy: Israel's Multiple Others and the Birth of the Gentile [Oxford: Oxford University Press 2018] 23-27).

31 Akadyjski termin nakru oznacza przede wszystkim kogoś źle nastawionego, o złej woli, a nawet wroga.

32 Obcy w tym fragmencie określeni są dodatkowo jako „nieobrzezani na sercu i ciele”. Na temat dyskusji, czy to jedna, czy dwie grupy zob.: M.A. Awabdy, „YHWH Exegetes Torah: How Ezekiel 44:7-9 Bars Foreigners from the Sanctuary", JBL 131/4 (2012) 685-703.

33 זָz zob. także Kpł 22,10.12; Hi 19,15; Ps 109,11; Prz 5,10; Iz 29,5; 61,5 (przez kontrast); Jr 3,13. נָכרךר zob.: Wj 12,43; 21,8; 2Sm 22,46; Ab 1,11. Do tekstów tych należałoby jeszcze dołączyć cały szereg wyroczni przeciw ludom obcym - jedynie dla przykładu: Am 1,3-2,3; Iz 13-23; So 2,4-15; Jr 46-51; Ez 25-32.35; Jl 4; w całości Ab i Na; Mi 4,1-4 - więcej zob.: Lang, „Die Fremden”, 11-13. Do powyższych tekstów należałoby dodać także teksty modlitewne, np.: Ps $58 ; 69 ; 83 ; 137 ; 139$. Voltaire (,Essai sur les moeurs et l'esprit des nations” [red. R. Pomeau] [Paris: Garnier frères 1963] I, 159-160) nie bez przyczyny zauważył, że ,gdyby Bóg wysłuchał wszystkich modlitw Swojego ludu, na świecie zostaliby już tylko sami Żydzi”. 
Brak tych - krytycznych wobec obcych - tekstów w hasłach słownikowych czy popularnych komentarzach biblijnych może być spowodowany thumaczeniem słów pochodnych od נכר w kontekście negatywnym nie przez „obcy” czy „przybysz”, ale zastępowanie ich innymi terminami. Przykładem tego zjawiska w Biblii Tysiaclecia może być fragment Ab 12, gdzie w potrójnym paralelizmie

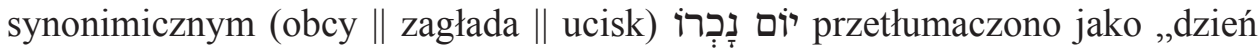
nieszczęścia”, czy Hi 31,3 gdzie נֵֶֶר thumaczone jest jako „klęska”.

Warto podkreślić, że żaden obcy, bez względu na to jak był określany, z wyjątkiem nadzwyczajnych sytuacji, nigdy nie cieszył się takimi samymi prawami jak Izraelita, choć fragment Pwt 17,15, zakazujący osadzenia na tronie kogoś obcego (איש נָכְִרִי), wydaje się sugerować, że niektórzy obcy mogli sprawować w Izraelu także bardzo wysokie funkcje, np. Uriasz Hetyta (2 Sm 11) czy Ittaja z Gat (2 Sm 18,2). Mimo to obcy, nawet jeśli w wyjątkowych sytuacjach przyznawano mu jakieś przywileje, pozostawał zawsze obcym ${ }^{34}$.

Wyjątkowy (pozytywny) kontekst użycia pochodnego od נכר przymiotnika נָכבְרִ znajdujemy w modlitwie Salomona (1 Krl 8,41-43.60). Król prosząc Boga o wysłuchanie wznoszonych w nowo wybudowanym przybytku modlitw, wśród

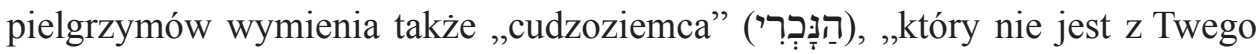
ludu, Izraela, a jednak przyjdzie z dalekiego kraju przez wzgląd na Twe imię" (1 Krl 8,41). Łaskawość JHWH wobec niego ma być świadectwem dla wszystkich narodów ziemi (w. 43).

W późnych tekstach biblijnych do ludów obcych zaczęto stosować także ter-

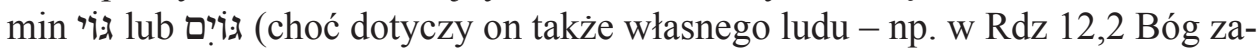

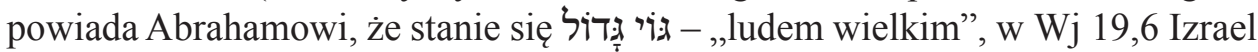

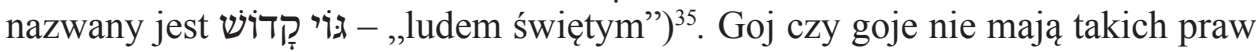

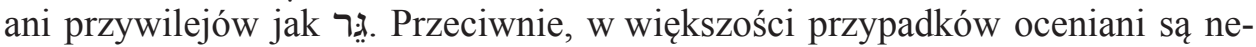
gatywnie: Kpł 18,28: „wymiociny”; Iz 40,15-17: „nic nie znaczą”; Kpł 25,44: „źródło pozyskiwania niewolników”; Pwt 12,30: „pokusa/zły przykład”; Iz 64,1: „wrogowie" itp. $)^{36}$.

34 Tezę tę wbrew pozorom potwierdza fragment Kpł 25,35, gdzie własny brat, jeśli popadnie w nędzę

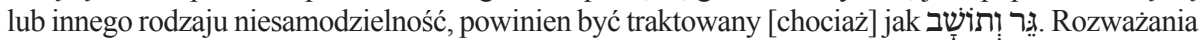
na temat Kpł 25,35-37 w kontekście odniesień do obcych zob.: B. Wells, „The Quasi-Alien in Leviticus 25", 135-156; A.C. Hagedorn, Die Anderen im Spiegel: Israels Auseinandersetzung mit den Völkern in den Büchern Nahum, Zefanja, Obadja und Joel (BZAW 414; Berlin: De Gruyter 2011).

35 Na temat tego terminu zob. obszerne studium ewolucji jego znaczenia (od neutralnego ludu/ludów do przeważnie pejoratywnego określenia nie-Żydów): Ophir, Rosen-Zvi, Goy: Israel's Multiple Others.

36 Przeglądowe opracowanie opisanych i postulowanych zachowań wobec obcych w Starym Testamencie zob.: Ch. Schäfer-Lichtenberger - L. Schottroff, „Fremde/Flüchtlinge”, Sozialgeschichtliches Wörterbuch zur Bibel (red. F. Crüsemann et al.) (Gütersloh: Gütersloher Verlaghaus 2009) 158-162. 
Ślad oczekiwań wobec władcy w odniesieniu do obcych i przybyszów znajduje się być może w Prz 31. Jest to szereg rad i pouczeń skierowanych do Lemuela przez jego matkę. Lemuel to postać tajemnicza i różnie identyfikowana. W Prz 31,1 przedstawiony jest jako król. W tradycji żydowskiej utożsamiany jest z Salomonem lub Ezechiaszem. Jeśli słowo מ்ֵַָָׁ odczytamy jako nazwę miasta, Lemuel byłby władcą asyryjskim lub arabskim. W wersecie 8 . matka radzi mu,

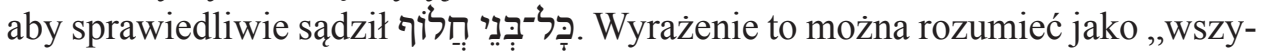
scy wędrowcy, przechodnie". Ponieważ pouczenie to pojawia się paralelnie do przemawiania w imieniu niemych, $\mathrm{z}$ wersetu tego możemy wyciągnąć dwojakie wnioski. Po pierwsze, wędrowiec, przybysz był osobą o niskim statusie społecznym, pozbawioną wielu praw, słabszą stroną w sporze. Po drugie, jeśli właściwie rozumiemy ten werset, oczekiwano, że król będzie gwarantem sprawiedliwego traktowania tego typu - narażonych na skrzywdzenie - osób ${ }^{37}$.

\section{Obowiązki i prawa obcych i przybyszów}

Prawa gościnności obowiązywały nie tylko gospodarzy, ale nakładały cały szereg zobowiązań na korzystających z gościny. Obcy, będący wędrowcami, oraz przybysze, którzy osiedlili się w ziemi Izraela, musieli między innymi bezwzględnie podporządkować się obowiązującym w Izraelu prawom (np. Pwt 31,12), nie mogli ich łamać, nawet jeśli odnosiły się wyłącznie do wierzeń Izraelitów. Tak było np. w przyjętych w wielu krajach, a zakazanych w Izraelu praktykach kultowych (Kpł 20,2: kara śmierci za złożenie ofiary z dziecka w kulcie Molocha).

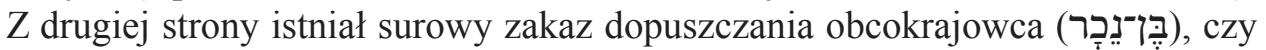
nawet osiadłego przybysza (תָּשָ - w obu przypadkach 1.poj.), do obchodów święta Paschy (Wj 12,43.45.49). Wyjątek stanowił jedynie obcy o statusie רגֵ który mógł być dopuszczony do ceremonii pod warunkiem nawrócenia na judaizm całej rodziny (czego znakiem miało być obrzezanie „wszystkich męskich potomków jego domu" - Wj 12,48). Dopiero wtedy nabywał on pełnię praw (przynajmniej w sprawach kultu) przysługujących Izraelicie: „Takie samo prawo będzie

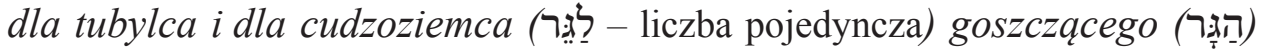
pośród was ${ }^{\prime 38}$. W powyższym rozporządzeniu uwagę zwraca wyraźna zmiana

37 Trudno jednoznacznie wskazać, czy postulat ten wypływał z tradycji izraelskiej, czy stanowił echo kultur sąsiednich.

38 Cudzoziemiec, który przyjmie wiarę i dostosuje się do prawa Bożego, może liczyć na łaskawość JHWH, zob. $1 \mathrm{Krl}$ 8,41-43 oraz Iz 56,6-7 (na temat odniesień do obcych w tej perykopie zob.: V. Haarmann, ,'Their Burnt Offerings and their Sacrifices will be Accepted on my Altar' (Isa 56:7) Gentile Yhwh-Worshipers and their Participation in the Cult of Israel", The Foreigner and the Law: Perspectives from the Hebrew Bible and the Ancient Near East [red. R. Achenbach - R. Albertz - 


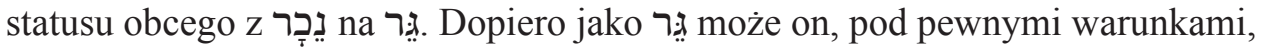
włączyć się w obchody Paschy. Uzupełnieniem powyższych rozporządzeń jest wyjątek zaznaczony w Pwt 23,8-9, zgodnie z którym udział w obchodach Paschy mogą brać także potomkowie Egipcjanina, ale dopiero „w trzecim pokoleniu”39. Tekst ten poucza ponadto: „Nie będziesz się brzydził Edomitą, bo jest twoim bratem". Należy jednak zaznaczyć, że jest to swego rodzaju dopełnienie surowego zakazu dopuszczania do zgromadzenia Izraelitów Ammonity czy Moabity (Pwt 23,4: ,...nawet w dziewiątym pokoleniu, nie wejdzie do zgromadzenia Pana na wieki...”). Nakaz dotyczący Edomity nie łamie reguły, ale nieco łagodzi jej wymowę w stosunku do mieszkańców Edomu. Z Ezd 4,1-3 dowiadujemy się, że powracający z deportacji babilońskiej odmówili współudziału w odbudowie Świątyni Jerozolimskiej przesiedleńcom osiadłym w Izraelu za panowania Asarhaddona (680-669 przed Chr.), czyli przed ok. 150 laty. W niczym nie pomogły nawet zapewnienia o przywiązaniu do wiary i tradycji Izraela ${ }^{40}$. Jak widać, obcokrajowcy lub ludzie traktowani jako obcy, mimo nakazu gościnności, byli przyjmowani do wspólnoty Izraela z dużymi oporami, chociaż w wyjątkowych sytuacjach, zapewne w zależności od czasu powstania danej regulacji i aktualnego kontekstu politycznego, do niektórych odnoszono się z nieco większą życzliwością.

W ściśle określonych okolicznościach obcy o statusie mog mogli otrzymać przydział ziemi. O przypadku takim mówi Ez 47,21-23¹, gdzie znajdujemy polecenie, aby kraj podzielić jako dziedzictwo dla dwunastu pokoleń Izraela „...i dla

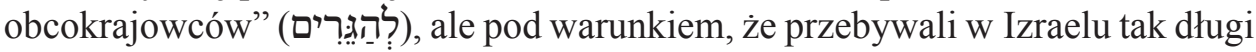
czas, żeby doczekać się zrodzonego w Izraelu potomstwa. Zdecydowanie inaczej traktowano obcych o innym statusie. W Wj 23,32-33 znajdujemy wyraźny

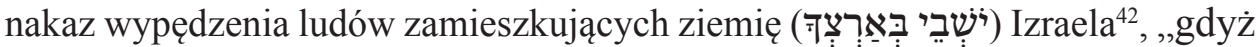
przywiedliby cię do grzechu przeciw Mnie. Mógłbyś oddawać cześć ich bogom, co byłoby dla ciebie zgubą".

J. Wöhrle] [BZABR 16; Wiesbaden: Harrassowitz 2011] 157-171 oraz S.S. Tuell, „The Priesthood of the 'Foreigner': Evidence of Competing Polities in Ezekiel 44:1-14 and Isaiah 56:1-8", Constituting the Community: Studies on the Polity of Ancient Israel in Honor of S. Dean McBride Jr [red. J.T. Strong - S.S. Tuell] [Winona Lake, IN: Eisenbrauns 2005] 183-204; Ch. Nihan, „Ethnicity and Identity in Isaiah 56-66", Judah and Judeans in the Achaemenid Period: Negotiating Identity in an International Context [red. O. Lipschits - G.N. Knoppers - M. Oeming] [Winona Lake, IN: Eisenbrauns 2011] 77-81).

39 Zob. także: Wj 12,48, 20,10; Kpł 16,29.

40 Mimo to w tekście nazwani są wrogami (צִרְרים) Judy i Beniamina (Ezd4,1a).

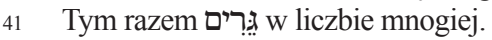

42 Sam Bóg pomoże Hebrajczykom wypędzić Kananejczyków (w. 23.27-28). 


\section{Pomagać czy nie pomagać?}

Biblijne nakazy dotyczące traktowania obcych wydają się być bardzo niekonsekwentne, a nawet ze sobą sprzeczne. Raz nakazują bezwzględną gościnność i życzliwość wobec przybysza, innym razem wyrażają wobec niego pogardę, a nawet wrogość. Tak jaskrawe sprzeczności są jednak tylko pozorne. Po pierwsze, teksty nakazujące życzliwe i gościnne przyjmowanie obcego, przybysza, wędrowca, kierowane są do pojedynczych Izraelitów, którzy m.in. przez pamięć na nieszczęścia ich przodków, nie powinni pozostawiać bez pomocy obcokrajowca w potrzebie. Drugą grupę stanowią ostrzeżenia skierowane przede wszystkim do ludu Izraela (Kpł 22,25; Lb 1,51; Ne 9,2; 13,30; Ps 54,5; 144,7.11; Iz 1,7; Jr 2,25; Ez 44,7-9 i in.). Ten, jako całość, ma się obcych strzec, a najlepiej gdyby w ogóle unikał z nimi kontaktów. A.P. Pauw zauważa, że nawet Boża gościnność miała swoje limity. Kiedy JHWH szykuje radosną ucztę eschatologiczną dla „wszystkich ludów”, równocześnie zapowiada zniszczenie Moabu (Iz 25,10-12). Kiedy zapowiada obfity posiłek dla swoich sług, ogłasza odrzucenie dla pozostałych (Iz 65,13) ${ }^{43}$.

Jeszcze wyraźniej oś podziału pomiędzy nakazami gościnności i ostrożności widać w określeniach, jakie stosuje się do obcych. Najbardziej pozytywnym pośród nich jest termin רג, który używany jest także w odniesieniu do Izraelitów przebywających na obczyźnie. W przypadku określania za jego pomocą obcych, występuje najczęściej w liczbie pojedynczej. W liczbie mnogiej termin ten na określenie nieizraelitów pojawia się trzykrotnie: $w$ informacji $2 \mathrm{Sm} \mathrm{4,3}$ o ucieczce zasymilowanych Gibeonitów z miasta Beerot w pokoleniu Beniamina do Gittaim, gdzie zostali „przybyszami aż po dzień dzisiejszy”; w 1 Krn 22,2 i Ps 146,9 w różnych kontekstach na określenie zbioru pojedynczych przypadków (obcych, których Dawid zaangażował do budowy Domu Bożego, lub uciśnionych, którzy ufają Bogu; obok obcych także: głodni, jeńcy, niewidomi, sieroty, wdowy). Terminu tego nie użyto na określenie jakiegokolwiek ludu przybywającego do Izraela. Powinności wobec רגֵ odnoszą się więc nie do całych grup ludnościowych, ludów, narodów, ale do pojedynczych osób, co najwyżej relatywnie niewielkich grup. Mimo że w tekście hebrajskim jest to ewidentne, tłumacze często odstępują od przekładu dosłownego. W języku hebrajskim istnieje wprawdzie zjawisko singularis collectivus ${ }^{44}$, ale w żadnej z wyżej omawianych perykop nie ma ani konieczności ${ }^{45}$, ani nawet potrzeby odwoływania się do takiej interpretacji (czyli przekład rzeczownika w liczbie pojedynczej

43 Inne cytowane przez niego przykłady to: Ps 23,5; So 1,7 oraz nowotestamentowe: Mt 22,13; Łk 1,53 i Ap 19.

44 Użycie liczby pojedynczej rzeczownika w znaczeniu zbiorowym.

45 Spowodowanej albo potrzebą zachowania sensu zdania, albo np. liczbą mnogą użytego czasownika. 
na rzeczownik w liczbie mnogiej w języku tłumaczenia). O tym, że w przypadku praw i regulacji odnoszących się do גִ גa mamy do czynienia z pojedynczymi przybyszami świadczy nie tylko forma gramatyczna, ale także rodzaj regulacji i częste zestawienie z sytuacją wdów i sierot. Co więcej, konkretne zobowiązania, jakie nakładane są na Izraelitów, sugerują, że chodzi o problemy jednostek, pojedynczych przypadków, a nie dużych grup ludności (wynikające z nich prawa dotyczą także sierot i wdów, por. Kpł 19,9-10 lub Pwt 24,19-21). Po drugie,ר nie ma w Biblii Hebrajskiej charakteru stricte etnicznego i określa w ogromnej większości przypadków specyficzny rodzaj „obcego”, a mianowicie kogoś, kto, szukając pomocy, całkowicie podporządkowuje się prawom gospodarza. Jest to więc nie tyle obcy, co „gość”. „Obcy” czy „obce ludy” określane są zupełnie innymi terminami. Właśnie wtedy pojawiają się ostrzeżenia i nakazy separacji, a nawet eksterminacji.

\section{Ostrzeżenia dotyczące ludów obcych}

Nie ulega wątpliwości, że w starożytności broniono własnych granic przed niekontrolowanym ruchem obcych. Świadczą o tym liczne dowody archeologiczne, m.in. twierdze i warownie strzegące granic oraz placówki wojskowe kontrolujące szlaki handlowe. Dowody na ochronę granic znajdujemy także w Biblii. Kiedy Hebrajczycy mieli przechodzić przez Edom, musieli najpierw prosić jego króla o pozwolenie. Ostatecznie takiego pozwolenia nie otrzymali, a król Edomu wysłał przeciw nim armię (Lb 20,14-21).

Izrael był zagrożony ze strony innych ludów niemal przez całą swoją historię. Jednak okresem szczególnie interesującym pod tym względem był przełom VI i V w. przed Chr. Powracający z deportacji babilońskiej Judejczycy zastali w swojej ojczyźnie licznych imigrantów. W czasie prawie 50-letniej nieobecności w kraju szeroko pojętych elit, wpływy obcych kultur zaczęły dominować. W Księdze Ezdrasza znajdujemy bardzo gorzkie wyrzuty skierowane do mieszkańców Judei, że nie trzymali się z daleka od obcych narodów (,,i ich okropności” 9,1-2 ${ }^{46}$ ), a nawet brali sobie za żony dziewczęta spoza Izraela (por. 2 Krn 36,14). Takie postępowanie kapłan Ezdrasz nazwał „przestępstwem” i kazał oddalić obce

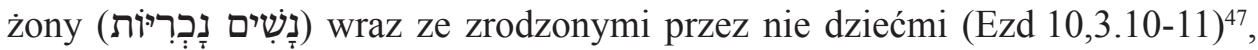

46 Nehemiasz, jako przykład negatywnych konsekwencji tego typu małżeństw, przywołuje historię króla Salomona, który uległ namowom cudzoziemskich żon i pozwolił na budowę pogańskich ołtarzy (Ne 13,26-27).

47 Prawo to zostało przyjęte (Ezd 10,14.19.44) i wykonane (Ne 9,2). Byli jednak i tacy, którzy się mu nie podporządkowali (Ezd 10,15). Na temat wewnątrzbiblijnych kontrowersji dotyczących małżeństw mieszanych zob.: D.K. Bartoszewicz, Instytucje biblijne (Warszawa: WAW 2003) 49. 
a w efekcie definitywnie odłączyć się od obcych ludów. Ezdrasz wskazuje bratanie się z obcymi $(9,10-12)$ jako równocześnie przyczynę i skutek upadku Izraela i surowo nakazuje, by nie troszczyć się „o pomyślność ich [ludów obcych] i szczęście" oraz obiecuje, że podporządkowanie się temu nakazowi przyniesie Izraelowi trwałą pomyślność ${ }^{48}$. Nehemiasz $(9,2)$ dodaje, że w efekcie odłączono

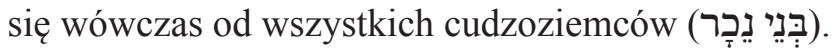

W Deuteronomium znajdujemy jeszcze bardziej radykalne nakazy sposobu postępowania z obcymi ludami. Polecenia te skierowane były rzekomo do Hebrajczyków powracających z niewoli egipskiej, jednak zawierające je teksty powstawały mniej więcej w tym samym okresie, w którym przeprowadzano reformy Ezdrasza i Nehemiasza i wyjątkowo dobrze oddają ducha sporów tego czasu $^{49}$. Znajdujemy w nich m.in. bardzo surowe nakazy eksterminacji obcych, którzy mogli zagrażać czystości wiary Izraela. Pierwszy z nich to Pwt 7,1-6, w którym występuje zapowiedź wyniszczenia przez samego JHWH narodów pierwotnie zamieszkujących Kanaan: „JHWH, Bóg twój, odda je [narody Kanaanu] tobie, a ty je wytępisz, obłożysz je klątwą, nie zawrzesz z nimi przymierza i nie okażesz im litości” (Pwt 7,2).

Drugi tego rodzaju nakaz znajduje się w tzw. kodeksie deutornomicznym (rozdziały 15-18), a w jego ramach, we fragmencie poświęconym prawom obowiązującym w czasie prowadzenia wojen. Pwt 20, 16-18 to nakaz JHWH, aby zabić wszystkich mieszkańców podbitych miast Kanaanu. Gdyby ktoś pozostał przy życiu, Izrael nauczyłby się czynić ,,wszystkie obrzydliwości”, które czynili poganie (w. 18). Wprawdzie oba teksty w momencie ich powstania były prawdopodobnie już nieaktualne (dotyczyły sytuacji sprzed kilkuset lat), ale doskonale ilustrują obawy okresu powygnaniowego. Te zaskakujące nakazy retrospektywne stanowiły swego rodzaju uzasadnienie przyczyn problemów, z jakimi borykał się Izrael w zetknięciu z obcymi kulturami ${ }^{50}$. Gdyby mianowicie w odpowiednim czasie wytępiono wszystkich Kananejczyków, nie doszłoby do nieszczęść, których przyczynę dostrzegano w nadmiernym zbliżeniu do obcych.

Jak widać zupełnie czym innym były przypadki gościny wobec wędrowca czy asymilowanie przybysza, a czym innym ,mieszanie się z narodami”, co ocenione było może nie zawsze tak radykalnie, jak w okresach kryzysów tożsamościo-

48 Tę samą argumentację oraz postulat do zerwania z praktyką małżeństw mieszanych znajdujemy w Księdze Nehemiasza - zob. Ne 10,30-31; 13,23-27. Tradycja biblijna nie jest w tym względzie jednoznaczna. W jej ramach znajdujemy także teksty zdające się pochwalać, a przynajmniej dopuszczać tego typu małżeństwa. Zob. Bartoszewicz, Instytucje biblijne, 62.

49 W kontekście naszych rozważań nie ma znaczenia, czy teksty te zostały stworzone dopiero w początkowym okresie perskim, czy miały swój pierwowzór w innych źródłach, np. jeszcze z czasów reformy Jozjasza (tak np. N. Lohfink, Theology of the Pentateuch: Themes of the Priestly Narrative and Deuteronomy [Edinburgh: T. \& T. Clark 1994] 187-194) lub nawet wcześniejszych.

Zob. P. Briks, „Cherem jako klątwa śmierci”, CTO 15/2 (2005) 6-16. 
wych czy politycznych, ale zawsze negatywnie. Nie znaczy to jednak, że obce ludy zawsze uważano za z gruntu złe i skazane na potępienie.

W tym samym mniej więcej okresie, w którym działali Ezdrasz czy Nehemiasz, powstały teksty, które sprzeciwiają się zamykaniu się wyłącznie w kręgu swoich i całkowitemu odcięciu się od obcych. Szczególnie wymowne są opowieść o Rut Moabitce (w Księdze Rut) oraz cała Księga Jonasza, która w różnych obrazach wskazuje, że deprecjonowani w tym czasie obcokrajowcy mogą okazać się bardziej posłuszni Bogu niż zadufany w sobie i pogardzający obcymi Izrael ${ }^{51}$. Mimo że niniejsze opracowanie odnosi się do norm społecznych i prawnych, należy zauważyć, że istnieje także pewna grupa tekstów, które akcentują teologiczny lub (najczęściej) eschatologiczny wymiar relacji z ludami obcymi. Należą do nich np. obietnice błogosławieństwa ( $\operatorname{Rdz} 12,2-3 ; 18,18$; $22,18 ; 28,14)$ czy prorockie zapowiedzi zbawienia dla wszystkich/wielu/niektórych ludów (Ps 67; Iz 2,2-3 ${ }^{52}$; Iz 14,1 ${ }^{53}$; 52,8-10; 56,6-8 ${ }^{54}$; 60,2-5; 66,18; Jr 3,17; Dn 7,14; Za 8,21-23; So 3,9-10; Ml 1,11 i in.). Niejednokrotnie zbawienie to uzależnione jest jednak od całkowitego poddania się lub nawet oddania się Izraelowi w poniżającą niewolę (np. Iz 14,1-4; 49:20-26; 60,10-14). Zestawienie tych tekstów prowadzi do wniosku, że poglądy na temat właściwego stosunku do obcych były w tamtym czasie znacząco zróżnicowane i szukanie w Biblii jednoznacznego przekazu na ten temat musi zakończyć się niepowodzeniem.

Obce ludy opisywane są w Biblii Hebrajskiej nie tylko jako zagrożenie czystości wiary, ale niekiedy wręcz zagrożenie egzystencjalne. Wśród wielu obietnic prorockich dotyczących Ziemi Obiecanej i praw, jakimi cieszyć się w niej będzie Izrael, poczesne miejsce zajmują obietnice bezpieczeństwa ze strony obcych ludów (szczególnie wymowne są perykopy Ez 28,24; 39,26b czy Iz 33,17-20a). $\mathrm{Z}$ kolei brak tego bezpieczeństwa interpretowany był jako kara dla niewiernego ludu. Właśnie obcy wskazywani byli jako źródło szczególnego niebezpieczeństwa albo narzędzie kary ${ }^{55}$. Historia pokazała wielokrotnie, że obawy Izraelitów nie były całkiem bezpodstawne.

51 Zob. P. Briks, „Księga Jonasza jako element dyskusji nad założeniami reformy Państwa Izraelskiego w okresie perskim", SBO 1 (2009) 91-106.

52 Por. jednak zapowiedź zniszczenia wszystkich ludów na końcu czasów Iz 8,9;34,2;Ab 1; Za 12,1-10; 14,12 i wiele innych, także dotyczących potępienia poszczególnych ludów obcych.

53 Tutaj z kolei mowa jest o przyjęciu innych narodów do „domu Jakuba” - ale jedynie jako niewolników i służących - Iz 4,2; por. 40,17.

54 Wyjątkowa obietnica złożona obcym określonym jako בְנִ הַ: ,którzy się przyłączyli do JHWH”.

55 Szczególnie wymowna jest tu wyrocznia Jr 5,15-17, zapowiadająca karę dla Izraela w postaci starożytnego narodu z daleka, budzącego przerażenie i niosącego śmierć oraz zniszczenie. Podobny wydźwięk mają wyrocznie przeciw królowi Tyru (Ez 28,6-7.10), które nie odnoszą się oczywiście bezpośrednio do Izraela, ale stanowią przykład realnego lęku przed agresją obcych, w tych przypadkach tłumaczoną jako kara Boża. Ez 7,20-25 (także w odniesieniu do króla Tyru). 


\section{Podsumowanie}

Analiza tekstów tworzących biblijne normy postępowania wobec obcych i przybyszów ukazuje przede wszystkim ich różnorodność, a ujęta w nich skala zaleceń jest bardzo szeroka - od heroicznej wręcz gościnności aż po nakazy bezwzględnej eksterminacji. Dokładniejsza analiza terminologii oraz kontekstu poszczególnych nakazów i wzorców pozwala jednak w pewien sposób uporządkować wynikający z tych tekstów przekaz. Oczywiście nie jest to przekaz, który można zastosować bezpośrednio i wprost do rozwiązywania obecnych problemów na styku różnych cywilizacji czy kultur. Zestawienie to stanowi jednak uczciwy przegląd całości norm dotyczących podejścia do obcych i każe zauważyć złożoność tego zagadnienia w Biblii.

Po pierwsze, w tekstach Biblii Hebrajskiej istnieje wyraźne rozróżnienie pomiędzy pojedynczymi wędrowcami czy obcymi, którzy szukają lepszego życia, pracy, szanują izraelskie prawo oraz obyczaje i podporządkowują się im, a ludami, które albo Izraelowi w jakikolwiek sposób zagrażały, albo, pozostając pomiędzy Izraelitami, mogły stanowić zagrożenie dla jego tożsamości. Głównym kryterium tego podziału nie jest więc rozróżnienie pomiędzy odmiennymi ludami (na złe i dobre). Każdy obcy lud, nie tylko nastawiony wrogo czy chcący odwieść Izraela od tradycji czy wiary, stanowił niebezpieczeństwo przez sam fakt pojawienia się pośród Izraelitów. Pouczenia odnośnie do tego typu ,intruzów” oscylowały pomiędzy daleko idącą ostrożnością a całkowitym unikaniem kontaktów, ze zrywaniem już nawiązanych włącznie, nawet jeśli chodziłoby o własne żony i poczęte z nimi dzieci. W skrajnych przypadkach Bóg nakazywał obcych eksterminować, choć należy podkreślić, że niektóre z tego typu tekstów są jedynie nakazami retrospektywnymi. $\mathrm{Z}$ drugiej strony, bardzo silne w swojej wymowie są teksty zapowiadające błogosławieństwo, czy nawet zbawienie dla obcych ludów, albo te nakazujące Izraelowi być dla obcych świadectwem dobroci Boga. Trzeba jednak zauważyć, że są to teksty odnoszące się do wymiaru teologicznego, a większość z nich dotyczy działania Boga dopiero w czasach ostatecznych.

Po drugie, nawet pojedynczy obcy są w Biblii Hebrajskiej oceniani bardzo odmiennie. W tekście hebrajskim pojawiają się różne terminy określające obcego czy przybysza. Najważniejsze z nich to

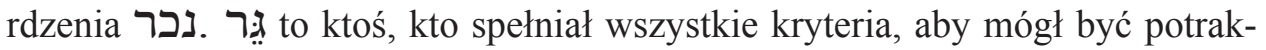
towany jako gość. Przychodził w dobrych zamiarach, w pełni akceptował obowiązujące w społeczności gospodarza prawa, tradycje, porządki, obyczaje itp. W żadnym przypadku nie stanowił zagrożenia dla moralności czy wiary przyjmującej społeczności. Takiego przybysza, jeśli potrzebował pomocy, należało, przez pamięć na własną historię, przyjąć i ugościć. Inaczej sprawa miała się z ob- 
cymi określanymi terminami pochodnymi od נכר. Ci przeważnie pojawiali się w większej liczbie, ale nawet pojedynczy stanowili zagrożenie dla tożsamości Izraela. Hołdowali innym bogom i innym wartościom. Oczywiście nie wykluczało to możliwości ich nawrócenia, ale takowe było przedstawiane jako znak szczególnej mocy Boga (np. 2 Sm 22,45n; Ps 18,45; Iz 60,10-15). W praktyce Izraelici podchodzili do obcych z dużą dozą ostrożności czy wręcz niechęcią ${ }^{56}$, a uzasadnienie takiej postawy (nie całkiem bezzasadnie) wywodzili z nauczania Biblii. Ewidentnym wyjątkiem w takiej postawie powinno być udzielenie pomocy i gościny komuś, kto jej nie tylko obiektywnie potrzebował, ale także pokornie się o nią ubiegał, szanując prawa i tradycje tego, u którego szukał schronienia.

\section{Bibliografia}

Achenbach, R., ,gêr - nåkhrî - tôshav - zâr. Legal and Sacral Distinctions regarding Foreigners in the Pentateuch", The Foreigner and the Law: Perspectives from the Hebrew Bible and the Ancient Near East (red. R. Achenbach - R. Albertz - J. Wöhrle) (BZABR 16; Wiesbaden: Harrassowitz 2011) 29-52.

Albertz, R., „From Aliens to Proselytes. Non-Priestly and Priestly Legislation Concerning Strangers", The Foreigner and the Law: Perspectives from the Hebrew Bible and the Ancient Near East (red. R. Achenbach - R. Albertz - J. Wöhrle) (BZABR 16; Wiesbaden: Harrassowitz 2011) 53-70.

Arterbury, A.E., „Abraham's Hospitality among Jewish and Early Christian Writers: A Tradition History of Gen 18: 1-16 and Its Relevance for the Study of the New Testament", Perspectives in Religious Studies 30 (2003) 359-376.

Awabdy, M.A., Immigrants and Innovative Law: Deuteronomy's Theological and Social Vision for the (Forschungen zum Alten Testament 2/67; Tübingen: Mohr Siebeck 2014).

Awabdy, M.A., „YHWH Exegetes Torah: How Ezekiel 44:7-9 Bars Foreigners from the Sanctuary”, Journal of Biblical Literature 131/4 (2012) 685-703.

Bartoszewicz, D.K., Instytucje biblijne (Warszawa: Wydawnictwo Archidiecezji Warszawskiej 2003).

Baumann, G. et al. (wyd.), Zugänge zum Fremden. Methodisch hermeneutische Perspektiven zu einem biblischen Thema (Linzer philosophisch-theologische Beiträge 25; Frankfurt am Main: Peter Lang 2012).

Biblia Tysiaclecia, wyd. 5 (Poznań: Pallottinum 2017).

Briks, P., „Cherem jako klątwa śmierci”, Colloquia Theologica Ottoniana 15/2 (2005) 6-16.

56 Symboliczną ilustracją stosunku Izraelitów do obcych i przybyszów (przynajmniej w okresie Drugiej Świątyni) były tablice umieszczone na balustradzie (tzw. soreg) oddzielającej Dziedziniec Pogan od Dziedzińca Izraela w Świątyni Jerozolimskiej. Na tablicach tych umieszczono inskrypcję: „Obcemu zabronione jest wejście za balustradę, na dziedziniec wokół przybytku. Ktokolwiek zostanie przyłapany, sam będzie odpowiedzialny za swoją, poniesioną w konsekwencji, śmierć". Na podstawie publikacji znaleziska z 1871 r. (Ch.S. Clermont-Ganneau): H.M. Cotton et al. (red.), Corpus Inscriptionum Iudaeae/Palaestinae. I. Jerusalem (Berlin - New York: De Gruyter 2010) 42. 
Briks, P., „Księga Jonasza jako element dyskusji nad założeniami reformy Państwa Izraelskiego w okresie perskim”, Scripta Biblica et Orientalia 1 (2009) 91-106.

Bultmann C., Der Fremde im antiken Juda. Eine Untersuchung zum sozialen Typenbegriff "ger" und seinem Bedeutungswandel in der alttestamentlichen Gesetzgebung (Forschungen zur Religion und Literatur des AT und NT 153; Göttingen: Vandenhoeck \& Ruprecht 1992).

Bunge, G., The Rublev Trinity: The Icon of the Trinity by the Monk-painter Andrei Rublev (Crestwood, NY - New York: St. Vladimir's Seminary Press 2007).

Cohen, J.M., „Abraham's Hospitality”, Jewish Bible Quarterly 34/3 (2006) 168-172.

Cotton, H.M. et al. (red.), Corpus Inscriptionum Iudaeae/Palaestinae. I. Jerusalem (Berlin - New York: De Gruyter 2010).

Ebach, R., Das Fremde und das Eigene: Die Fremdendarstellungen des Deuteronomiums im Kontext israelitischer Identitätskonstruktionen (Beihefte zur Zeitschrift für die alttestamentliche Wissenschaft 471; Berlin - Boston, MA: De Gruyter 2014).

Haarmann, V., ,'Their Burnt Offerings and their Sacrifices will be Accepted on my Altar' (Isa 56:7) Gentile Yhwh-Worshipers and their Participation in the Cult of Israel", The Foreigner and the Law: Perspectives from the Hebrew Bible and the Ancient Near East (red. R. Achenbach R. Albertz - J. Wöhrle) (BZABR 16; Wiesbaden: Harrassowitz 2011) 157-171.

Haarmann, V., JHWH-Verehrer der Völker. Die Hinwendung von Nichtisraeliten zum Gott Israels in alttestamentlichen Uberlieferungen (Abhandlungen zur Theologie des Alten und Neuen Testaments 91; Zürich: Theologischer Verlag 2008).

Hagedorn, A.C., Die Anderen im Spiegel: Israels Auseinandersetzung mit den Völkern in den Büchern Nahum, Zefanja, Obadja und Joel (Beihefte zur Zeitschrift für die alttestamentliche Wissenschaft 414, Berlin: De Gruyter 2011).

Hobbs, T.R., „Hospitality in the First Testament and the Teleological Fallacy”, Journal for the Study of the Old Testament 26 (2001) 3-30.

Hoffman, Y., „The Conception of 'Other Gods' in Deuteronomistic Literature”, Concepts of the Other in Near Eastern Religions (red. I. Alon - I. Gruenwald - I. Singer) (Israel Oriental Studies 14; Leiden - New York - Köln: Brill 1994) 103-118.

Jericke, D., „Hebron”, Das wissenschaftliche Bibellexikon im Internet (red. M. Bauks - K. Koenen S. Alkier) (Stuttgart 2006-2016) https://www.bibelwissenschaft.de/de/stichwort/20809/ [dostęp: 9.07.2019].

Lang, B., „Die Fremden in der Sicht des Alten Testaments”, Wahrnehmung des Fremden. Christentum und andere Religionen (red. R. Kampling - B. Schlegelberger) (Schriften der Diözesanakademie Berlin 12; Berlin 1996) 9-37.

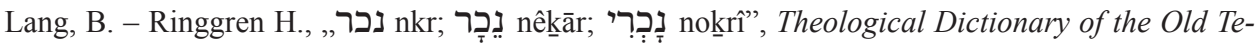
stament (red. G.J. Botterweck - H. Ringgren - H.-J. Fabry)(Grand Rapids, MI: Eerdmans 1998) IX, 423-432.

Lohfink, N., Theology of the Pentateuch: Themes of the Priestly Narrative and Deuteronomy, (Edinburgh: T. \& T. Clark 1994).

Martin, L.R., „Old Testament Foundations for Christian Hospitality”, Verbum et Ecclesia 35 (2014) 1-9.

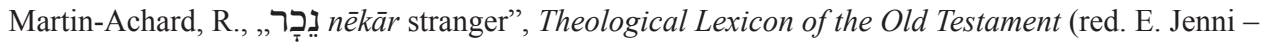
C. Westermann) (Peabody, MA: Hendrickson 1997) 942-944. 
Nihan, Ch., „Ethnicity and Identity in Isaiah 56-66”, Judah and Judeans in the Achaemenid Period: Negotiating Identity in an International Context (red. O. Lipschits - G.N. Knoppers M. Oeming) (Winona Lake, IN: Eisenbrauns 2011) 67-104.

Nihan, Ch., „Resident Aliens and Natives in the Holiness Legislation”, The Foreigner and the Law: Perspectives from the Hebrew Bible and the Ancient Near East (red. R. Achenbach - R. Albertz - J. Wöhrle) (BZABR 16; Wiesbaden: Harrassowitz 2011) 111-134.

Olyan, S.M., Rites and Rank: Hierarchy in Biblical Representations of Cult (Princeton, NJ: Princeton University Press 2000).

Ophir, A., Rosen-Zvi I., Goy: Israel's Multiple Others and the Birth of the Gentile (Oxford: Oxford University Press 2018).

Pawłowski, Z., „O Panie, nie omijaj twego stugi. Gościnność Abrahama w horyzoncie tego, co niemożliwe (Rdz 18,1-15)", Biblica et Patristica Thoruniensia 9/2 (2016) 55-69.

Pytel, J., Gościnność w Biblii. Studium źródłowo-porównawcze (Poznań: Księgarnia Świętego Wojciecha 1990).

Pytel, J., „Pojęcie gościnności w literaturze biblijnej i greckiej”, Ruch Biblijny i Liturgiczny 30 (1977) 172-181.

Ramírez Kidd, J.E., Alterity and Identity in Israel. The ר in the Old Testament (Beihefte zur Zeitschrift für die alttestamentliche Wissenschaft 283; Berlin - New York: de Gruyter 1999).

Schäfer-Lichtenberger, Ch. - Schottroff, L., „Fremde/Flüchtlinge”, Sozialgeschichtliches Wörterbuch zur Bibel (red. F. Crüsemann et al.) (Gütersloh: Gütersloher Verlaghaus 2009) 158-162.

Schreiner, J. - Kampling, R., Bliźni, obcy, nieprzyjaciel z perspektywy Starego i Nowego Testamentu (Kraków: WAM 2001).

Smith, W.R., Lectures on the Religion of the Semites (New York: D. Appleton 1889).

„Strangers and Gentiles”, https://www.jewishvirtuallibrary.org/strangers-and-gentiles [dostęp 23.03.2019].

Tuell, S.S., „The Priesthood of the 'Foreigner': Evidence of Competing Polities in Ezekiel 44:1-14 and Isaiah 56:1-8", Constituting the Community: Studies on the Polity of Ancient Israel in Honor of S. Dean McBride Jr (red. J.T. Strong - S.S. Tuell) (Winona Lake, IN: Eisenbrauns 2005) 183-204.

Voltaire (F.-M. Arouet), Essai sur les moeurs et l'esprit des nations (red. R. Pomeau) (Paris: Garnier frères 1963) I.

Wells, B., „The Quasi-Alien in Leviticus 25”, The Foreigner and the Law: Perspectives from the Hebrew Bible and the Ancient Near East (red. R. Achenbach - R. Albertz - J. Wöhrle) (BZABR 16; Wiesbaden: Harrassowitz 2011) 135-156.

Zehnder, M., Umgang mit Fremden in Israel und Assyrien. Ein Beitrag zur Anthropologie des "Fremden" im Licht antiker Quellen (Beiträge zur Wissenschaft vom Alten und Neuen Testament 168; Stuttgart: W. Kohlhammer 2005).

Zwickel, W., „Das Heiligtum von Mamre”, Biblische Notizen 101 (2000) 27-28. 